$\begin{array}{r}\text { Phinisi Integration Review } \\ \text { Vol. 1, No.2, Agustus 2018 Hal 162-176 } \\ \text { Website: } \underline{\text { http://ojs.unm.ac.id/pir }} \\ \hline \text { p-ISSN: 2614-2325 dan e-ISSN: 2614-2317 } \\ \hline\end{array}$

\title{
Double Burden Perempuan Penjual Ikan Di Awarangnge Desa Siddo Kecamatan Soppeng Riaja Kabupaten Barru (Suatu Kajian Sosiologi Gender)
}

\author{
Mariamin Ibrahim \\ Program Pascasarjana Universitas Negeri Makassar \\ Email: mariaminibrahim@yahoo.com
}

\begin{abstract}
Abstrak. Tujuan penelitian ini adalah (i) Untuk memahami dan menganalisis motivasi yang mendorong perempuan melakukan peran ganda pada perempuan penjual ikan (ii) Untuk memahami dan menganalisis dampak yang dialami oleh perempuan penjual ikan dalam melaksanakan peran ganda. Jenis penelitian adalah penelitian Kuantitatif deskriptif dengan lokasi penelitian di Desa Siddo Kecamatan Soppeng Riaja Kabupaten Barru. Informan dalam penelitian ini adalah ibu rumah tangga yang memiliki peran ganda. Teknik pengumpulan data dalam penelitian yaitu wawancara, observasi dan dokumentasi. Teknik analisis data dalam penelitian ini Purposive Sampling dengan kriteria (i) Perempuan yang sudah menikah, (ii) Perempuan yang berusia 30-50 Tahun, (iii) Perempuan yang bekerja di pagi hari dan di sore hari. Hasil penelitian ini menunjukan bahwa motivasi yang mendorong perempuan melakukan peran ganda pada perempuan penjual ikan di Awarannge Desa Siddo Kecamatan Soppeng Riaja Kabupaten Barru adalah Faktor Ekonomi (Kebutuhan Finansial) dan Faktor Pendidikan. Sedangkan dampak peran ganda yang dilakukan oleh perempuan penjual ikan. Dampak positif antara lain menambah penghasilan rumah tangga serta terbangun rasa saling pengertian antar anggota keluarga. Sedangkan dampak negatif terbatasnya Komunikasi dan sosialisasi dalam keluarga dan warisan terhadap profesi.
\end{abstract}

Kata Kunci: Perempuan Penjual Ikan, Peran Ganda

\begin{abstract}
The objectives of this research are (i) To understand and analyze motivation that encourage women to do double roles in women fish sellers (ii) To understand and analyze the impact experienced by women fish sellers in implementing multiple roles. The type of this research is descriptive Quantitative research with research location in Siddo Village, Soppeng Riaja District of Barru Regency. Informants in this study are housewives who have multiple roles. Data collection techniques in research are interview, observation and documentation. Data analysis techniques in this study Purposive Sampling with criteria (i) married women, (ii) Women aged 30-50 Years, (iii) Women who work in the morning and in the afternoon. The results of this study indicate that the motivation that encourages women to do double roles in women fish sellers in Awarannge Siddo Village Soppeng Riaja District Barru Regency is Economic Factors (Financial Needs) and Educational Factors. While the impact of multiple roles performed by women fish sellers. Positive impacts include increasing household income as well as building a sense of mutual understanding among family members. While the negative impact of the lack of communication and socialization in the family and inheritance to the profession.
\end{abstract}

Keywords : Female Fishmonger, Double Role 


\section{PENDAHULUAN}

Perkembangan ekonomi di Indonesia yang semakin pesat membuat kebutuhan rumah tangga semakin meningkat. Kurangnya pendapatan yang dihasilkan suami sebagai kepala rumah tangga dalam mencari nafkah membuat sebagian besar wanita ikut serta bekerja guna memenuhi kebutuhan keluarga. Dengan latar pendidikan yang minim, membuat sejumlah wanita mencari pekerjaan yang sesuai dengan kemampuan yang dimilikinya. Dalam sektor perdagangan maupun sektor industri lainnya banyak dijumpai wanita bekerja baik sebagai buruh, pembantu rumah tangga, buruh cuci, babysitter dan lain-lain.

Pembagian kerja laki-laki dan perempuan yang dilihat pada aktivitas fisik yang dilakukan, dimana perempuan bertanggung jawab atas pekerjaan rumah tangga, sedangkan laki-laki bertanggung jawab atas pekerjaan nafkah. Pekerjaan rumah tangga tidak dinilai sebagai pekerjaan karena alasan ekonomi semata dan akibatnya pelakunya tidak dinilai bekerja. Permasalahan yang muncul kemudian adalah pekerjaan rumah tangga sebagai bagian dari pekerjaan non produksi tidak menghasilkan uang, sedangkan pekerjaan produksi (publik) berhubungan dengan uang. Uang berarti kekuasaan, berarti akses yang besar ke sumbersumber produksi, berarti status yang tinggi dalam masyarakat. Dalam perkembangan budaya, konsep tersebut di atas berakar kuat dalam adat istiadat yang kadang kala membelenggu perkembangan seseorang. Pantang keluar rumah, seorang anak perempuan harus mengalah untuk tidak melanjutkan sekolah, harus menerima upah yang lebih rendah, harus bekerja keras sambil menggendong anak, hanya karena dia perempuan (Sukesi, 2015: 15).

Ketidakadilan yang menimpa kaum perempuan akan memunculkan persepsi bahwa perempuan dilahirkan untuk melakukan pekerjaan yang jauh lebih terbatas jumlahnya dengan status pekerjaan rendah pula. Di negara berkembang, tingkat pendidikan yang sangat rendah dengan ketrampilan rendah pula, memaksa perempuan memasuki sektor informal yang sangat eksploitatif dengan gaji sangat rendah, jam kerja yang tak menentudan panjang, tidak ada cuti dengan bayaran penuh serta keuntungan-keuntungan lainnya
Pubjiwati Jojogyo (2005: 46) menjelaskan bahwa partisipasi perempuan bukan sekedar menuntut persamaan hak tetapi juga menyatakan fungsinya mempunyai arti bagi pembangunan dalam masyarakat Indonesia. Melihat potensi perempuan sebagai sumber daya manusia maka upaya menyertakan perempuan dalam proses pembangunan bukan hanya merupakan perikemanusiaan belaka, tetapi merupakan tindakan efisien. Karena tanpa mengikut sertakan perempuan dalam proses pembangunan berarti pemborosan dan memberi pengaruh negatif terhadap lajunya pertumbuhan ekonomi. Menurut Sukesi (2015:134) Partisipasi perempuan menyangkut peran tradisi dan transisi. Peran tradisi atau domestik mencakup peran perempuan sebagai istri, ibu dan pengelola rumah tangga. Sementara peran transisi meliputi pengertian perempuan sebagai tenaga kerja, anggota masyarakat dan manusia pembangunan. Pada peran transisi wanita sebagai tenaga kerja turut aktif dalam kegiatan ekonomis (mencari nafkah) di berbagai kegiatan sesuai dengan ketrampilan dan pendidikan yang dimiliki serta lapangan pekerjaan yang tersedia.

Kita selalu berharap bahwa para wanita selalu menmpatkan diri dan selalu memposisikan kodrat yang dia miliki dalam berumah tangga. Hal ini tidak terlepas dalam kaedah agama islam. Perempuan merupakan pelayan dalam berumah tangga dan suami adalah tulang punggung dalam keluarga sebagai pencari nafkah untuk keluarga. Tapi hal yang menarik pada perempuan di Awarange Desa Siddo, karena perempuan atau para istri juga ikut mencari nafkah ntuk keluarga yakini menjadi penjual ikan. Keunikannya juga kitika para perempuan ini menjual hasil tangkapan dari suami mereka. Setelah menjual ikan, perempuan ini kembali kerumah masing-masing untuk menjalani tuntutan sebagai istri yaitu sebagai pelayan dalam rumah tangga seperti memasak, mencuci dan sebagainya.

Keadaan diatas menunjukan bahwa perempuan memiliki peran lebih dari satu atau peran ganda (double burden), bertugas mengurus rumah tangga dan juga mencari nafkah. Peran ganda menjadi fenomena dalam dunia kerja yang sering jumpai, tidak sedikit kaum wanita yang berpartisipasi dalam dunia industri. Sumbangan wanita dalam pembangunan ekonomi terlihat dari kecenderungan partisipasi wanita dalam 
angkatan kerja. Sebagai salah satu indikator, partisipasi dalam bidang ekonomi ditunjukkan dari laju peningkatan partisipasi wanita dalam angkatan kerja.

Peran perempuan disektor publik berdampak pada rumah tangganya, perempuan menjadi terbebani tugas ganda yaitu harus bertanggung jawab atas pekerjaanya di sektor publik maupun di sektor domestik. Sebab pada umumnya perempuan mempunyai lima macam kegiatan yaitu kegiatan sehari-hari berkaitan dengan rumah tangga, kegiatan mencari nafkah pada industri rumah tangga, kegiatan mencari nafkah pada kesempatan yang ada, kegiatan sosial dari masyarakat, dan kegiatan individual dan istirahat. (Abdullah, 2007: 21)

Keterlibatan perempuan yang sudah kentara tetapi secara jelas belum diakui di Indonesia membawa dampak terhadap peranan perempuan dalam kehidupan keluarga. Fenomena yang terjadi dalam masyarakat adalah semakin banyaknya perempuan membantu suami mencari tambahan penghasilan, selain karena didorong oleh kebutuhan ekonomi keluarga, juga perempuan semakin dapat mengekspresikan dirinya di tengah keluarga dan masyarakat. Keadaan ekonomi keluarga mempengaruhi kecenderungan perempuan untuk berpartisipasi di pasar kerja, agar dapat membantu meningkatkan perekonomian keluarga.

Nampaknya sebagian besar masyarakat Indonesia sepakat bahwa peranan perempuan tidak bisa dipisahkan dengan peran dan kedudukan mereka dalam keluarga. Mengingat di masa lalu, perempuan lebih banyak terkungkung dalam peran sebagai pendamping suami dan pengasuh anak. Namun seiring dengan kemajuan ekonomi dan meningkatnya pendidikan wanita maka banyak ibu rumah tangga dewasa ini yang tidak hanya berfungsi sebagai manajer rumah tangga, tetapi juga ikut berkarya di luar rumah.

Kondisi peran ganda (double burden) yang dimainkan oleh perempuan dapat dilihat diberbagi tempat di Indonesia termasuk di Propinsi Sulawesi Selatan terkhusus Desa Siddo Kecamatan Soppeng Riaja Kabupaten Barru. Peran ganda (double burden) perempuan di tempat tersebut dilihat pada perempuan penjuan ikan di Awarannge.

\section{TINJUAN PUSTAKAN}

\section{Peran Ganda (Double Bulden)}

Peran ganda merupakan dua peran yang dijalankan oleh seorang saja dalam menjalankan suatu tugas yang memang sudah menjadi hal yang dikerjakannya (bekerja) dan juga salah satu peran itu telah menjadi kodrat yang memang telah melekat dari dahulu pada diri dan tanggung jawabnya (ibu rumah tangga) didalam sebuah keluarga. Dalam keluarga konvensional, suami bertugas mencari nafkah dan istri yang mengurus rumah tangga. Tetapi kini, dengan tumbuhnya kesempatan bagi wanita bersuami untuk bekerja, pada pola kekeluargaan segera berubah dan muncul apa yang disebut sebagai dualisme karir.

Dikutip dalam Faqih (2006:75-76) Dualisme (persamaan karir) karir terjadi bila suami maupun istri sama-sama bekerja dan mengurus rumah tangga secara bersama pula. Didalam hubungannya dengan posisi masingmasing, setiap pasangan suami istri memiliki cara yang berbeda di dalam mengatur peranannya dalam pekerjaan dan rumah tangga. Wanita yang bekerja secara part time umumnya menganggap bahwa pekerjaan hanyalah sekedar hobbi dan hanya menduduki prioritas kedua dibawah kepentingan keluarga. Tetapi dalam keluarga dualisme karir egalitarian, suami istri bekerja tidak hanya sekedar mencari nafkah tetapi juga dalam persaingan untuk mendapatkan posisi yang sama dalam pengambilan keputusan serta berbagai aktivitas dalam keluarga.

Dikutip dalam Suryadi (2004: 12) Peran ganda adalah dua peran atau lebih yang di jalankan dalam waktu yang bersamaan. Dalam hal ini peran yang dimaksud adalah peran seorang perempuan sebagai istri bagi suaminya, ibu bagi anak-anaknya, dan peran sebagai perempuan yang memiliki karir di luar rumah. Peran ganda ini dijalani bersamaan dengan peran kaum perempuan sebagai istri dan ibu dalam keluarga, seperti menjadi mitra suami dalam membina rumah tangga, menyediakan kebutuhan rumah tangga, serta mengasuh dan mendidik anak-anak.

Menurut Dowling sebagaimana yang dikutip dalam Ihromi (2006: 30) menjelaskan Peran ganda disebutkan dengan konsep dualisme kultural, yakni adanya konsep domestik sphere (lingkungan domestik) dan publik sphere (lingkungan publik). Kedua pengertian ini menggambarkan keterpisahan peranan dan pembagian pekerjaan yang ketat antara laki-laki dan perempuan dalam masyarakat yakni peranan kaum perempuan umumnya terbatas pada lingkungan dosmestik saja (lingkungan khas 
bagi perempuan) dan laki-laki umumnya dominan pada lingkungan publik (lingkungan khas bagi kaum laki-laki).

Berdasarkan pendapat diatas dapat disimpulkan bahwa peran ganda merupakan keadaan perempun yang melakukan kegiatan rumah tangga, mengurus keperluan suami dan anak-anaknya juga kegiatan diluar rumah tangga seperti berdagang, menjadi tenaga pendidik, menjadi politisi dan lain sebagainya guna mendapat penghasilan tambahan bagi kebutuhan rumah tangga.

\section{Peran Ganda (Double Burden) Perempuan}

a. Perempuan Dalam Ranah Domestik

Keluarga konvensional, suami bertugas mencari nafkah sedangkan istri bertugas mengurus rumah tangga, tetapi dengan tumbuhnya kesempatan bagi wanita bersuami untuk bekerja, maka pola kekeluargaan segera berubah dan muncul apa yang disebut sebagai dualisme karir. Nilai-nilai tradisional yang ada dalam masyarakat memang dapat menjadi tekanan sosial. Seorang wanita dikalangan tertentu atau yang memiliki status sosial tertentu atau kalangan bangsawan akan tetap mengingat tentang 3M, yaitu, masak, macak, manak (memasak, bersolek, melahirkan anak) sebagai tugas utamanya. (Faqih, 2006: 23)

Sebagaimana di jelaskan oleh Mayling, dkk (2006: 218) Fenomena wanita yang bekerja diluar rumah oleh banyak pihak masih dianggap sebagai sesuatu yang relatif baru bagi masyarakat Indonesia. Oleh karena itu masyarakat biasanya mengikuti sepak terjang wanita dengan menggunakan "kaca pembesar" dan langsung menilai pantas atau tidaknya berdasarkan nilai-nilai yang berlaku. Dengan meningkatkan peran wanita sebagai pencari nafkah keluarga dan kenyataan bahwa mereka juga berperan untuk meningkatkan kedudukan keluarga (family status production), maka bertambah pula masalah-masalah yang timbul. Kedua peran tersebut sama-sama membutuhkan waktu, tenaga, dan, perhatian, sehingga kalau peran yang satu dilakukan dengan baik, maka yang lain terabaikan sehigga timbullah konflik peran. Seorang istri yang menjadi ibu rumah tangga dan pencari nafkah (berperan ganda) harus memenuhi tugas dan kewajibannya sebagai ibu rumah tangga dan diharapkan dapat menjalankan peranannya sebagai seorang istri dan pencari nafkah. (Ihromi, 2009: 3)

Sisi lain Saptari dan Holzer (2007: 19) menjelaskan bahwa apa yang dikaitkan dengan karakteristik wanita dalam bentuknya yang ideal biasanya disebut dengan "feminitas". Misalnya ditemukan di negara-negara Asia Tenggara ialah gambaran soal kerendahan hati dan ketaatan seorang wanita. Dikatakan bahwa sifat ini di internalisasikan oleh kaum wanita melalui sosialisasi dalam keluarga. Ciri lain yang banyak dikaitkan dengan wanita adalah soal keterampilan tangannya dan diajarkan pula dalam rumah. Banyak literatur tentang kerja wanita di pabrik. Pandangan ideal mengenai feminitas wanita ini yang mempengaruhi jenis pekerjaan yang diberikan padanya.

Wanita merupakan seorang perempuan yang sudah menginjak masa dewasa. Dimana seorang wanita ini mempunyai peran dalam kehidupan ber rumah tangga untuk mengatur segala urusan rumahtangga. Terutama memberikan kasih sayang kepada anak-anaknya. Dalam pengertian umum tentang studi wanita berarti segala studi yang fokus perhatiannya tentang wanita. Misalnya studi tentang sejarah wanita, tentang faktor-faktor yang mempengaruhi posisi wanita dimasyarakat yang berbeda-beda, tentang wanita dicerminkan dalam sastra atau kesenian, dan bagaimana feminitas diciptakan dan subyektifitas terbentuk, bisa digolongkan dalam studi wanita. Namun apabila wanita dilihat secara historis, yaitu sebagai perwujudan dari kesadaran yang semakin besar akan hubungan-hubungan khusus atas dasar jenis kelamin.

Sedangkan dikutip dalam Suratiah, dkk (2009: 44) menjelaskan Peranan wanita dalam lingkungan keluarga sangat penting, oleh karena itu sesuai dengan kedudukan tugas dan fungsinya, maka wanita dalam keluarga mempunyai peranan sebagai berikut.

a) Wanita sebagai anggota keluarga

Dalam hukum islam, kedudukan wanita dalam keluarga sangat mulia dan terhormat, oleh karena itu seorang wanita harus dihormati dan dihargai, ibu dalam kelompok keluarga merupakan tumpuan harapan pemenuhan rasa aman dan rasa kasih sayang setiap anggota keluarganya, hal yang dimaksud dapat memberikan dampak positif terhadap perkembangan dan kesehatan fisik dan mental setiap anggota masyarakat.

b) Wanita sebagai ibu rumah tangga

Peranan wanita sebagai ibu rumah tangga dalam keluarga yang bahagia, yang mana wanita berperan sebagai ibu yang melahirkan anak dan merawat, memelihara dan juga mengayomi anggota keluarganya. 
c) Wanita sebagai istri

Peranan wanita sebagai istri yang mendampingi suami, tidak kalah pentingga tidak kalah pentingnya dengan peranan istri sebagai ibu rumah tangga. Melaksanakan tugas sebagai istri tentu akan banyak menenui bermacammacam cobaab dan ujian, juga mendapatkan kesempurnaan dalam keluarga. Berdasarkan hal demikian diatas bisa disimpulkan bahwa peran perempuan dalam ranah domestik tetapi menjadi kewajiban bagi seorang perempuan. Seorang perempuan akan dikatakan sukses apabila dapat membangun rumah tangga yang baik, tanpa mengabaikan tanggung jawabnya sebagai istri bagi suaminya dan tanggung jawab sebagi ibu bagi anak-anaknya.

\section{Perempuan Dalam Ranah Publik}

Wanita masuk dalam dunia kerja secara umun, biasanya terdorong untuk mencari nafkah karena tuntungan ekonomi keluarga yang terus meningkat, dan tidak seimbang dengan pendapatan yang tidak ikut meningkat. Hal ini banyak terjadi pada lapisan masyarakat bawah, bisa kita lihat bahwa kontribusi wanita terhadap penghasilan keluarga dalam lapisan menengah kebawah sangat tinggi. Dikutip dalam Suratiah, dkk (2009:44) Ware dalam bukunya "Dilema Wanita Antra Industri Rumah Tangga dan Aktifitas Domestik" yang mengatakan bahwa ada dua alasan pokok yang melatatar belakangi keterlibatan wanita dalam bekerja adalah:

1) Keharusan, dalam artian sebagai refleksi dari kondisi ekonomi rumah tangga yang rendah, sehingga bekerja dalan meningkatkan pendapatan ekonomi rumah tangga adalah sesuatu yang sangat penting.

2) Memilih untuk bekerja sebagai refleksi dari kondisi sosial ekonomi pada tingkat menengak ke atas. Bekerja bukan sematamata diorentasikan untuk mencari tambahan dana untuk ekonomi keluarga tapi merupakan salah satu bentuk aktualisasi diri mencari wadah untuk sosialisasi.

Jika demikian, maka gambaran diatas paling tidak telah menunjukkan bahwa sesungguhnya masuknya wanita dalam ekonomi keluarga merupakan kenyataan bahwa wanita adalah sumber daya yang produktif. Oleh sebab itu diperlukan juga perbaikan kondisi dan penciptaan kesempatan kerja yang sesuai dengan realitas dan perubahan yang ada saat ini.

Dikutip dalam Soetrisno (2007: 34) tentang peran wanita, pemerintah juga telah menentukan pula peran yang seharusnya dilakukan oleh wanita dalam pembangunan melalui apa yang kita kenal dengan panca tugas wanita, yaitu:

a) Wanita sebagai istri, supaya bisa mendampingi suami sebagai kekasih dan sahabat yang bersama-sama membina keluarga yang bahagia.

b) Wanita sebagai pendidik dan pembina generasi mudah supaya anak-anak dibekali kekuatan jasmani dan rohani dalam menghadapi segala tantangan zaman dan menjadi manusia yang berguna bagi nusa dan bangsa.

c) Wanita sebagai ibu rumah tangga supaya rumah tangga menjadi tempat yang aman dan teratur bagi seluruh anggota keluarga.

d) Wanita sebagai tenaga kerja dalam progresi untuk menambah penghasilan keluarga.

e) Wanita sebagai anggota organisasi masyarakat terutama organisasi wanita.

Perubahan peran perempuan dalam rumah tangga pada dasarnya disebabkan oleh faktor ekonomi dalam keluarga. Sering dijumpai bahwa penghasilan suami yang tidak dapat memenuhi kebutuhan hidup mereka dalam keluarga. Hal itulah yang membuat perempuan tergerak untuk berperan dalam mencari nafkah, agar kehidupan ekonomi keluarga mereka dapat bertahan untuk mencukupi kebutuhan hidup keluarga. Bainar (2008: 264) menyatakan bahwa perkembangan zaman dan kondisi sosial ekonomi kadang kala menyebabkan peranan seorang ibu bukan lagi hanya semata-mata sebagai ibu rumah tangga, melainkan juga sebagai perempuan karir atau pekerja.

\section{Peran Ganda (Double Burden) Perempuan Dalam Perspektif Sosiologi Gender}

Gender berasal dari bahasa latin "genus", berarti tipe atau jenis. Gender merupakan ciri-ciri peran dan tanggung jawab yang dibebankan pada perempuan dan laki-laki, yang ditentukan secara sosial dan bukan berasal dari pemberian Tuhan atau kodrat. Konsep gender adalah hasil konstruksi sosial yang diciptakan oleh manusia, yang sifatnya tidak tetap, berubah-ubah serta dapat dialihkan dan dipertukarkan menurut waktu, tempat dan budaya setempat dari satu jenis kelamin kepada jenis kelamin lainnya. Konsep gender juga termasuk karakteristik atau ciri-ciri laki-laki dan perempuan yang diciptakan oleh keluarga dan atau masyarakat, yang dipengaruhi oleh budaya 
dan interpretasi agama. Misalnya, secara umum, pekerjaan memasak, mengurus anak, mencuci selalu disebutkan hanya sebagai pekerjaan perempuan. Pandangan seperti ini merupakan ciptaan masyarakat dari budaya tertentu, padahal pekerjaan tersebut dapat juga dipertukarkan dengan laki-laki atau dapat dikerjakan oleh lakilaki. Namun pandangan ini bisa saja berbeda dari satu budaya dengan budaya yang lain. Karakteristik atau ciri-ciri ini menciptakan pembedaan antara laki-laki dan perempuan yang disebut pembedaan gender. Ini sering mengakibatkan peran sosial yang berbeda antara laki-laki dan perempuan. Peran ini dipelajari dan berubah-ubah dari waktu ke waktu dan dari suatu tempat ke tempat lain. Peran sosial atau yang sering disebut peran gender ini berpengaruh terhadap pola relasi kuasa antara perempuan dan laki-laki yang sering disebut sebagai relasi gender.

Gender adalah sebuah kata kuno yang diberi makna baru. (Nunuk. P. Muniarti, 2004 : 78) dalam perkembangannya, gender menjadi sebuah ideologi. Gender sebagai istilah yang dianggap baru pada prinsipnya adalah proses membahasakan atau memberi simbol terhadap perilaku dan fenomena yang sesungguhnya telah lama ada dan berlaku dalam kehidupan manusia. Gender adalah pembedaan antara laki-laki dan perempuan yang bukan didasari pada faktor biologis dan jenis kelamin (seks) sebagai kodrat Tuhan yang secara permanen memang berbeda. Lebih lanjut (Nunuk.P.Muniarti, 2004: 89) menjelaskan bahwa Seks diyakini sebagai biologi tubuh, sedangkan gender lebih mengacu pada asumsi dan praktik budaya yang mengatur konstruksi sosial laki-laki, perempuan dan relasisosial antara keduanya. Gender merupakan pembedaan antara bentuk nyata dan jenis kelamin yang diberikan, sehingga membentuk kategori umum yaitu maskulin dan feminim.

Tetapi terkadang sering disamakan antara konsep gender dengan konseps seks atau jenis kelamin. Gender dan seks dapat diibaratkan sebagai dua sisi mata uang yang tidak dapat dipisahkan. Artinya jika berbicara mengenai gender tidak terlepas dari jenis kelamin. Namun kedua konsep ini sangat berbeda makna dan pengertiannya. Konsep jenis kelamin adalah kenyataan secara biologis yang membedakan antara manusia dimana lebih diidentikkan dengan perbedaan tubuh laki-laki dan perempuan.

\section{Teori Gender}

Para feminis dalam membangun wacana kesetaran gender seringkali memulainya dengan pembedaan antara definisi seks dan gender. Dua istilah tersebut lazim kita anggap sama, yakni bermakna jenis kelamin manusia yang terdiri dari lelaki atau perempuan dan sifatnya mutlak harus diterima sebagaimana mestinya. Namun, menurut mereka hal tersebut hanya terbatas pada pembagian manusia secara biologis, inilah yang didefinisikan sebagai seks, sedangkan gender diberi definisi baru sebagai kelompok atribut dan perilaku yang dibentuk secara kultural yang ada pada laki-laki (maskulin) atau perempuan (feminim). Perbedaan biologis antara laki-laki dan perempuan yang meliputi perbedaan organorgan seks dan juga hormon tidak menjadi perdebatan, namun pendapat tentang ada atau tidaknya pengaruh dari perbedaan tersebut dalam pembentukan sifat maskulin atau feminim masih belum menemukan kata sepakat. Akhirnya, dari dua argumen ini kemudian muncul konsep nature dan nurture. (Abdullah, 2007:86)

\section{Teori Nature}

Secara etimologi nature diartikan sebagai karakteristik yang melekat atau keadaan bawaan pada seseorang atau sesuatu, diartikan juga sebagai kondisi alami atau sifat dasar manusia. (Pubjiwati. 2005:14). Dalam kajian gender, term nature diartikan sebagai teori atau argumen yang menyatakan bahwa perbedaan sifat antar gender tidak lepas dan bahkan ditentukan oleh perbedaan biologis (seks). Disebut sebagai teori nature karena menyatakan bahwa perbedaan lelaki dan wanita adalah natural dan dari perbedaan alami tersebut timbul perbedaan bawaan berupa atribut maskulin dan feminim yang melekat padanya secara alami. Jadi, seharusnya dalam menyikapi perbedaan yang ada bukan dengan menghilangkannya, melainkan dengan menghapus diskriminasi dan mencipatakan hubungan yang serasi. (Soetrisno. 2007:45)

\section{Teori Nurture}

Secara etimologi nurture berarti kegiatan perawatan/pemeliharaan, pelatihan, serta akumulasi dari faktor-faktor lingkungan yang mempengaruhi kebiasaan dan ciri-ciri yang nampak. Terminologi kajian gender memaknainya sebagai teori atau argumen yang menyatakan bahwa perbedaan sifat maskulin dan feminim bukan ditentukan oleh perbedaan biologis, melainkan konstruk sosial dan pengaruh faktor budaya. Dinamakan nurture karena faktor-faktor sosial dan budaya 
menciptakan atribut gender serta membentuk stereotip dari jenis kelamin tertentu, hal tersebut terjadi selama masa pengasuhan orang tua atau masyarakat dan terulang secara turun-temurun. Karena adanya faktor budaya di dalamnya, argumen ini seringkali juga disebut sebagai konsep culture. Tradisi yang terus berulang kemudian membentuk kesan di masyarakat bahwa hal tersebut merupakan sesuatu yang alami. (Faqih, 2006:96)

\section{METODE}

Metode penelitian pada dasarnya merupakan cara ilmiah untuk mendapatkan data dengan tujuan dan kegunaan. Berdasarkan hal tersebut terdapat empat kata kunci yang perlu diperhatikan yaitu, cara ilmiah, data, tujuan, dan kegunaan. Sedangkan penelitian adalah suatu kegiatan untuk menggali dan mengetahui suatu fenomena yang ada pada masyarakat, baik yang terjadi pada saat ini maupun pada masa yang lalu.

Sesuai dengan masalah yang diteliti yaitu Peran Ganda Perempuan Ganda (Double Burden) Pada Perempuan Penjual Ikan di Awarannge Desa Siddo Kecamatan Soppeng Riaja Kabupaten Barru maka jenis penelitian ini adalah penelitian deskriptif. Sukmadinata (2009:72) menjelaskan Penelitian deskriptif adalah suatu bentuk penelitian yang ditujukan untuk mendeskripsikan fenomena-fenomena yang ada, baik fenomena alamiah maupun fenomena buatan manusia. Fenomena itu bisa berupa bentuk, aktivitas, karakteristik, perubahan, hubungan, kesamaan, dan perbedaan antara fenomena yang satu dengan fenomena lainnya

Menurut Riyanto (2007:34) Penelitian deskriptif tidak dimaksudkan untuk menguji hipotesis tertentu, melainkan lebih pada menggambarkan apa adanya suatu gejala, variabel, atau keadaan. Namun demikian, tidak berarti semua penelitian deskriptif tidak menggunakan hipotesis. Penggunaan hipotesis dalam penelitian deskriptif bukan dimaksudkan untuk diuji melainkan bagaimana berusaha menemukan sesuatu yang berarti sebagai alternatif dalam mengatasi masalah penelitian melalui prosedur ilmiah.

Penelitian deskriptif tidak hanya terbatas pada masalah pengumpulan dan penyusunan data, tapi juga meliputi analisis dan interpretasi tentang arti data tersebut. Oleh karena itu, penelitian deskriptif mungkin saja mengambil bentuk penelitian komparatif, yaitu suatu penelitian yang membandingkan satu fenomena atau gejala dengan fenomena atau gejala lain, atau dalam bentuk studi kuantitatif dengan mengadakan klasifikasi, penilaian, menetapkan standar, dan hubungan kedudukan satu unsur dengan unsur yang lain.

Sedangkan pada proses penelitian ini, teknik pengambilan sample dengan metode Purposive Sampling. Pada Penelitian ini juga, ada beberapa kriteria informan yang menjadi dasar penelitian. Kriteria tersebut adalah sebagai berikut: (1) Perempuan yang sudah menikah, (2) Perempuan yang berusia 30-50 Tahun, (3) Perempuan yang bekerja di pagi hari dan di sore hari.

Sesuai dengan masalah yang diteliti yaitu Peran Ganda Perempuan Ganda (Double Burden) Pada Perempuan Penjual Ikan di Awarannge Desa Siddo Kecamatan Soppeng Riaja Kabupaten Barru, maka lokasi penelitian ini dilaksanakan di Desa Siddo Kecamatan Soppeng Riaja Kabupaten Barru.

Sasaran penelitian atau yang menjadi informan dalam penelitian ini adalah perempuan berperan ganda pada perempuan penjual ikan Awarange Desa Siddo Kecamatan Soppeng Riaja Kabupaten Barru yang terdiri dari informan kunci, informan biasa serta informan tambahan.

Instrumen penelitian ini adalah peneliti itu sendiri, oleh karena itu, peneliti sebagai instrumen juga harus divaliditasi seberapa jauh peneliti kualitatif siap melakukan penelitian yang selanjutnya terjun kelapangan. Validitas terhadap peneliti sebagai instrumen meliputi, validitas terhadap pemahaman metode penelitian kualitataif, penguasan wawasan terhadap bidang yang diteliti. Alat yang digunakan dalam mengumpulkan data yaitu, pedoman wawancara, kamera, dan alat penunjang lainnya (Sugiyono, 2012: 61-62). Teknik pengumpulan data yang digunakan dalam penelitian ini adalah. Observasi/pengamatan, Metode Interview (Wawancara) dan Metode Dokumentasi

Teknik analisis data dalam penelitian ini merujuk pada teknik analisis data yang dikemukakan oleh Milles \& Hubberman. Dikutip dalam Riyanto (2007: 16-20) Menurut Milles \& Hubberman terdapat tiga teknik analisisi data kualitatif, yaitu reduksi data, penyajian data dan penarikan kesimpulan (verifikasi). Proses ini berlangsung terusmenerus selama penelitian berlangsung, bahkan sebelum data benar-benar terkumpul. Reduksi 
Data, Penyajian Data dan Penarikan Kesimpulan

\section{HASIL DAN PEMBAHASAN}

Deskripsi hasil analisis data diawali dengan pemaparan data tentang gambaran umum latar penelitian. Adapun latar penelitian yang dideskripsikan adalah berkaitan dengan gambaran umum Desa Siddo Kecamatan Soppeng Riaja Kabupaten Barru, kemudian dilanjutkan dengan deskripsi data hasil penelitian yang berkaitan dengan fokus penelitian, yang terdiri dari: Motivasi dasar penyebab Doubel Burden pada perempuan penjual ikan di Awarannge Desa Siddo Kecamatan Soppeng Riaja Kabupaten Barru, serta dampak yang dialami oleh perempuan penjual ikan di Awarannge Desa Siddo Kecamatan Soppeng Riaja Kabupaten Barru dalam melaksanakan Doubel Burden.

\section{Gambaran Umum Latar Penelitian}

2. Motivasi Penyebab Doubel Burden Pada Perempuan Penjual Ikan di Awarannge Desa Siddo Kecamatan Soppeng Riaja Kabupaten Barru

Pada bagian ini akan di deskripsikan data hasil penelitian yang berkaitan motivasi penyebab Doubel Burden perempuan penjual ikan di Awarannge Desa Siddo Kecamatan Soppeng Riaja Kabupaten Barru. Deskripsi data ini berdasarkan hasil wawancara dengan beberapa informan yang dapat memberikan informasi terhadap masalah yang diteliti, terutama yang berstatus sebagai penjual ikan dan menjadi ibu rumah tangga. Disamping mengobservasi kondisi sosial masyarakat yang menjadi sasaran dalam penelitian serta foto dan dokumentasi yang dapat memberikan jawaban terhadap masalah yang diteliti.

Komplesitas kehidupan masyarakat di era industrialisasi menyebabkan tingging tingkatan kebutuhan yang diamali oleh individu dalam setiap keluarga. Bersama itu peran perempuan dalam kehidupan pun terus berubah untuk menjawab tantangan tuntutan kebutuhan itu. Tanpa terkecuali mengenai peran perempuan dalam meningkatkan kesejahteraan keluarga. Biasanya tulang punggung kehidupan keluarga adalah pria atau suami. Tetapi kini para perempuan banyak yang melakoni pekerjaan lain selain menjadi ibu rumah tangga, menjadi pegawai pada instansi tertentu, menjadi politis maupun akademisi. Bahkan terakhir menjadi pedagang menjual ikan, sebagaimana yang dialami oleh babarapa perempuan di Desa Siddo Kecamatan Soppeng Riaja Kabupaten Barru. Berdasarkan beberapa hasil wawancara dengan beberapa informan, ditemukan beberapa faktor penyebab perempuan menjual ikan di samping menjadi ibu rumah tangga. Faktor tersebut antara lain sebagai berikut:

\section{a. Faktor Ekonomi (Kebutuhan Finansial)}

Masalah ekonomi keluarga yang belum tercukupi menjadi alasan utama bagi seorang perempuan terlibat dalam ranah publik dengan menjadi pedagang dan penjual ikan. Dikutip dari hasil wawancara dengan salah seorang informan penjual ikan bernama Dahlia (37 Tahun) mengungkapkan bahwa menjadi pedagangan ikan bukanlah menjadi masalah karena dia menyadari bahwa kebutuhan ekonomi keluarga belum tercukupi. Apalagi kalau suami tidak memiliki pekerjaan yang dapat mencukupi kebutuhan keluarga. Berikut kutipan wawancaranya:

“.....menjual ikan tidak jadi masalah dan saya pun ikhlas tidak dan pernah mengeluh. Karena suami saya hanya menjadi buruh nelaya. Mana mungkin cukup kalau hanyan mengandalkan penghasilan dari suami saja....."

Dari penjelasan informan diatas dapat dilihat bahwa profesi menjadi pedagang ikan di pasar Awarannge merupakan pekerjaan yang wajar yang banyak dilakukan oleh ibu-ibu rumah tangga yang lain. Selama apa yang dilakukan mendapat restu dari suami dan kelurga. Disamping itu tanggung jawabnya pun sebagai ibu rumah tangga tetap dilaksanakan sebagaimana mestinya. Kebutuhan dan pelayanan terhadap suami dan anak-anaknya tidak pernah ditinggalkannya. Pengabdiannya sebagai ibu rumah tangga, memasak mencuci dan lain sebagainya dilakukan sebelum pergi ke pasar atau setelah pulang berjualan. Sehingga antara menjual ikan dan mengurus keluarga bisa dilakukan dalam waktu yang telah diatur dengan baik. Kalau berjualan pagi maka setelah pulang ibu Dahlia bisa melaksanakan tugas rumah tangganya, atau kalau jualan sore kegiatan rumah tangga bisa dilakukan di waktu pagi.

Upaya memenuhi kebutuhan ekonomi keluarga perempuan penjual ikan di desa Siddo memaksimalkan waktunya untuk menjual ikan tanpa mengorbankan waktu bagi keluarga. Dengan kata lain ibu-ibu menjual ikan tidak saja 
di pasar tetapi juga berjulan keliling. Berbeda dengan apa yang dilakukan oleh ibu Dahlia yang hanya berjualan di pasar saja, seorang informan bernama Nahira (48 Tahun) yang sering menjajakan ikan dagangannya berjalan keliling mengaku bahwa menjadi penjual ikan tidak boleh menjadi alasan untuk meninggalkan tugas rumah tangga. Berikut kutipan wawancara dengan informan tersebut:

".....menjual ikan bukan hal yang berat dan sulit jadi kalau seandainya mampu bagus untuk menambah kebutuhan rumah tangga. Saya paginya jualan di pasar, setelah di pasar saya berjualan keliling. Pulang berjualan bisa bersihbersih rumah atau apapun....."

Dari penjelasan informan diatas bahwa profesi menjual ikan bukanlah menjadi beban apalagi sampai meninggalkan tanggung jawab rumah tanggal. Dijelaskan juga bahwa dengan menjadi penjual ikan bisa menambah penghasilan keluarga. Ibu Nahira tidak saja menjual ikan pada pagi atau siang hari tetapi juga berjualan di malam hari. Maksimalisasi waktu berjualan dilakukan karena untuk memenuhi kebutuhan pendidikan anak disamping kebutuhan keluarga lainnya.

\section{b. Faktor Pendidikan}

Pendidikan merupakan hal yang terpenting dalam kehidupan manusia, hal ini karena dengan pendidikan semua bisa belajar dan mendaptkan ilmu pengetahuan. Dengan ilmu pengetahuan bisa merubah seseorang, baik pola pikir, kepribadian maupun ketrampilan. Setiap manusia khususnya masyarakat Indonesia berhak mendapatkan pendidikan yang layak, sebagaimana diamanatkan Undang-undang. Pendidikan bisa terjadi dan berlangsung dimana saja dan kapan saja, meskipun para ahli telah membagi pendidikan berlangsung kedalam tiga bentuk yaitu pendidikan formal, informal dan non formal.

Proses pendidikan ini berlangsung seumur hidup kepada setiap individu dalam kehidupan sosial masyarakat. Karena pendidikan menjadi modal utama dalam menghadapi persaingan hidup yang kian hari kian kuat. Oleh karean itu Era modernisasi seperti yang telah berlangsung sekarang adalah era yang sarat dengan persaingan diberbagai dimensi kehidupan. baik persaingan dibidang sosial, politik, hukum, ekonomi maupun dimensi lainnya. Tetapi kenyataan yang terjadi sungguh ironis. Ditengah berkembangnya pendidikan yang begitu pesat ternayat masih banyak masyarakat belum memiliki kesempatan untuk mendapatkan pendidikan yang layak, sebagaimana yang diamanatkan oleh undangundang. Kekurangan biaya menjadi alasan utama bagi mereka yang tidak bisa menempuh pendidikan.

Pendidikan tidak hanya di dominasi kaum laki-laki tetapi perempuan juga memilik hak yang sama. Kaum perempuan yang berpendidikan bukan berarti melepaskan perannya sebagai Ibu Rumah Tangga yakni memasak di dapur, mengurus anak-anak dan suami. Setinggi apapun jabatan dan pendidikan seorang wanita ia tidak akan terlepas dari kodrat dan fitrahnya yakni sebagai ibu rumah tangga. Jika kaum perempuan memiliki wawasan yang luas, maka ia akan mampu menghadapi disetiap permaslahan hidup, mampu memandang positif dari setiap permasalahan yang terjadi, sehingga menjadikannya bijaksana dalam menghadapi berbagai permasalahan hidup dan mampu mendidik anak-anaknya menjadi generasi penerus yang lebih baik. Karena perempuan merupakan bagian dari keluarga dan masyarakat yang sangat berpengaruh dalam membentuk generasi yang lebih baik.

Berdasakan data dan informasi yang didapat selama penelitian berlangsung maka dapat dilihat beberapa hal terkait Motivasi Penyebab Doubel Burden Pada Perempuan Penjual Ikan di Awarannge Desa Siddo Kecamatan Soppeng Riaja Kabupaten Barru, disamping karena factor ekonomi (finansial) factor lain adalah factor pendidikan. Sejumlah informan yang ditemui dalam penelitian yaitu ibu-ibu yang berDoubel Burden, satu sisi mereka menjadi ibu rumah tangga dan di sisi lain menjadi penjual ikan. Informan tersebut menjadi penjual ikan di Awarannge Desa Siddo diakibatkan karena kebutuhan ekonomi yang belum tercukupi. Disamping itu juga karena mereka tidak memiliki ketrampilan pendidikan yang memadai sebagai modal hidup dalam mencari nafkah.

Sejumlah informan tersebut rata-rata pendidikan terakhir hanya sampai Sekolah Dasar (SD) dan Sekolah Menengah Pertama (SMP). Dari keadaan itu dapat dilihat bahwa kemapuan dan ketrampilan yang dimiliki untuk tidak memungkinkan untuk mencari kekerjaan yang lebih menguntukan secara ekonomi, melainkan 
hanya menjadi ibu rumah tangga saja. Mereka pun merasa bersyukur memiliki pekerjaan samping sebagai penjual ikan. Untuk meningkatkan pendapatan ekonomi yang lebih baik pemerintah desa menawarkan kepada ibuibu penjual ikan di Desa Siddo untuk membuat abon ikan, dengan pertimbangan bahwa abon ikan lebih tinggi harganya dibandingkan dengan ikan biasa. Hanya saja ibu-ibu tersebut tidak setuju dengan kerana mereka menganggap bahwa membuat abon ikan membutuhkan waktu yang cukup lama dan proses yang panjang.

Berikut wawancara dengan sala satu informan bernama Suryanti (24 Tahun) saat ditanya peran pemerintah dalam membantu ibuibu tersebut. Berikut kutipan wawancaranya:

".....saya dan beberapa ibu-ibu lain yang jual ikan itu pernah ditawarkan oleh kepala desa untuk buat abon ikan, tapi buat abon ikan waktu lama bu....."

Dari penjelasan informan diatas dapat dipahami bahwa ada peran pemerintah dalam membantu ibu-ibu di desa Siddo terutama yang berprofesi sebagai penjual ikan. Hanya saja apa yang di usulkan oleh pemerintah tidak sesuai dengan keinginan warga setempat, disamping waktu yang lama untuk membuatnya juga dibutuhkan keahlian untuk mengolah ikan menjadi abon.

Latar belakang pendidikan yang rendah yang dialami oleh masyarakat desa Siddo menyebabkan mereka tidak mampu melakukan pekerjaan yang selain selain menjadi ibu rumah tangga dan penjual ikan. Meskipun sebenarnya diantara mereka ada yang memiliki keinginan untuk memilih pekerjaan yang lain selain menjual ikan, tetapi kendalanya mereka tidak punya ketrampilan. Seorang ibu penjual ikan bernama Suryanti (28 Tahun) pernah memiliki keinginan untuk bekerja di tokoh sebagai pelayanan tokoh, tetapi tidak diterima karena tidak punya ketrampilan. Berikut kutipan wawancara dengan ibu Fatimah.

“.....dulu sekali bu, pernah mau berkerja di Alfa Mart tapi saya di tanya ijazah saya, kata pengawai disana saya akan diterima kalau saya bisa computer......"

Dari penjelasan informan diatas dapat dilihat bahwa ketrampilan merupakan syarat utama bagi sesorang dalam bersaing di dunia kerja. Informan tersebut tidak diterima karena hanya melamar dengan menggunakan ijazah SMP, sisi lain tidak punya keahlian pendukung lainnya. Rasanya memang sulit untuk dilakukan apabila sesorang ingin bersaing di dunia kerja tanpa di dukung dengan ketrampilan dan keahlian, era komunikasi dan informasi memaksa sesorang untuk menguasai berbagi ketrampilan seperti mengaplikasikan computer dan sejenisnya. Disamping pengetahun yang memadai.

\section{Dampak Doubel Burden Perempuan} Penjual Ikan di Awarannge Desa Siddo Kecamatan Soppeng Riaja Kabupaten Barru a. Dampak Positif

1) Menambah penghasilan rumah tangga

Ketika perempuan berada dalam ruang publik dan menjalani berbagai macam pekerjaan tujuan utamanya adalah menghasilkan uang. Apalagi jika kondisi ekonomi rumah tangga tergolong lemah atau kondisi suami yang tidak bisa diandalkan dalam memenuhi kebutuhan keluarga sebagaimana mestinya. Tidak ada alasan bagi sang istri untuk tidak mencari pekerjaan atau menjalani pekerjaan tertentu. Sebab tanggung jawab rumah tangga adalah tanggung jawab bersama dan begitulah yang seharunya terjadi.

Wawancara dengan informan bernama Dahlia (37 Tahun) yang berprofesi penjual ikan mengemukakan bahwa keuantungan yang didapat dari menjual ikan sangat membantuk keluarga meskipun hasilnya tidak terlalu banyak, kisaran antara Rp. 20.000 sampai Rp. 70.000 bahkan lebih dari itu. Berikut kutipan wawancara dengan informan tersebut:

“.....pagi sampai sore bisa dapat Rp. 25.000 sampai 100.000 bu. Lumayan buat tambah-tambah kebutuhan keluarga, tapi terkadang tidak ada hasilnya juga....."

Dari hasil wawancara tersebut dapat dilihat bahwa penghasilan yang didapat terkadang bisa kurang dari itu. Tetapi berapa pun hasil yang didapat mereka tidak pernah mengeluh dan ikhlas menerimannya. Jika dibadingkan dengan berdiam diri di rumah tidak ada yang dapat mereka hasilkan. Tetapi ibu Nahira lebih rendah penghasilannya dibandingkan ibu Dahlia. Berikut kutipan wawancara dengan ibu Nahira (48 Tahun):

“.....sehari hanya RP.20.000 sampai Rp.70.000 saja bu, itu setelah jualan di pasar saja jualan lagi ditempat yang lain....."

Lebih lanjut informan tersebut mengatakan bahwa dirinya tidak saja berjualan di pasar tetapi berjualan di berbagai tempat salah satunya di jalan Poros Makassar-Pare. Sungguh 
hasil yang tidak begitu banyak. Tetapi mereka tetap semangat menjalani hari-harinya sebagai penjual. Seperti halnya yang disampaikan oleh Dahlia, ibu Nurhayati juga tidak banyak penghasilan yang di dapat dari menjual ikan. Berikut ketipan wawancara dengan informan tersebut:

“.....saya tidak jual di pasar bu saya jual keliling saja karna di pasar banyak juga orang yang jual ikan, keutungannya juga sedikit. Tapi kalau jual keliling bisa nyampe Rp. 100.000 per hari....."

\section{Pembahasan}

Berdasarkan data hasil penelitian yang telah dideskripsikan, maka masing-masing hasil penelitian dapat dilakukan pembahasan sesuai dengan fokus penelitian yang ada.

\section{Motivasi Penyebab Doubel Burden Pada Perempuan Penjual Ikan di Awarannge Desa Siddo Kecamatan Soppeng Riaja Kabupaten Barru}

Dewasa ini, perempuan memang sudah mendapatkan hak untuk bekerja dibandingkan dengan sejarah masa lampau. Tetapi masih saja terjadi perbedaan peran antara laki-laki dan perempuan. Banyak perempuan sekarang memiliki Doubel Burden, dan mayoritas yang berasal dari keluarga yang kurang mampu. Mereka harus membantu suami untuk mencari nafkah demi kebutuhan keluarga, dan setelah bekerja seorang perempuan juga harus melakukan pekerjaan rumah tangga. Hal ini terjadi karena kebiasaan yang terbawa sejak dulu. Perempuan harus memasak, melayani dan membersihkan rumah adalah stereotipe yang melekat pada masyarakat Indonesia secara umum dan masyarakat yang ada di desa siddo kacamatan soppeng riaja kabupaten baru secara khususnya.

Berbicara mengenai Doubel Burden, terutama Doubel Burden yang dilakukan oleh para ibu-ibu penjual ikan yang ada di desa Siddo Kecamatan Sopeng Riaja Kabupaten Barru merupakan para perempuan yang siap dalam konsekuensi apapun yang akan dihadapi dalam kehidupan keluarga maupun di masyarakat. Melihat kondisi yang ada, dalam menjalani kehidupannya, perempuan penjual ikan yang ada di Desa Siddo Kecamatan Soppeng Riaja Kabupaten Barru tetap menjalankan tugasnya sebagai ibu rumah tangga dengan baik dan menjalankan pekerjaan domestiknya, seperti mencuci, memasak, lain sebagainya. Tetapi, diluar tugas domestiknya sebagai ibu rumah tangga, ia tetap menjalankan kewajibannya sebagai pekerja di sektor publik yaitu menjadi penjual ikan. Semua pekerjaan tersebut dilakukan dalam satu waktu dan perempuan yang mempunyai Doubel Burden harus bisa membagi waktunya antar pekerjaan di dalam rumah maupun pekerjaan di luar rumah sesuai dengan profesinya masing-masing.

Diktuip dalam Ritzer (2013: 89) tentang teori Struktural Fungsional yang dikemukan oleh Talcot Parson, Masyarakat dibaratkan sebagai organisme biologis terdiri dari organorgan yang saling ketergantungan, hal ini menjelaskan bahwa setiap anggota keluarga mempunyai peran dan fungsinya masing-masing agar terciptanya kondisi yang harmonis. Untuk itu agar tetap tercapai kondisi yang harmonis maka seorang istri walaupun bekerja di ruang publik sebagai penjula ikan juga tetap menjalankan fungsinya sebagai ibu rumah tangga, menjadi ibu bagi anak-anaknya serta menjadi istri yang baik juga untuk suaminya, karena itulah fungsinya sebagai istri dan ibu di dalam keluarga. Oleh karena kondisi ekonomi belum tercukupi secara sempurna. Maka tidak salah kalau perempuan ikut membantu suami dalam mencari nafkah. Keadaan tersebut hampir semua dirasakan oleh para kelurga penjual ikan yang ada di Desa Desa Siddo Kecamatan Soppeng Riaja Kabupaten Barru

Jika dikutip dalam Khairuddin (2002:6) Mac Iver dan Page mengemukakan beberapa ciri-ciri keluarga sala satunya adalah adanya Ketentuan-ketentuan ekonomi yang dibentuk oleh anggota-anggota kelompok yang mempunyai ketentuan khusus terhadap kebutuhan-kebutuhan ekonomi yang berkaitan dengan kemampuan untuk mempunyai keturunan dan membesarkan anak. Sedangkan dikutip dalam Abu Ahmadi (2002 : 247 ), Secara sederhana dapat dikemukakan bahwa tugas orang tua sebagai berikut: (a) Menstabilisasi situasi keluarga dalam arti stabilisasi situasi ekonomi rumah tangga; (b) Mendidik anak dan (c) Pemeliharaan fisik dan psikis keluarga, termasuk di sini kehidupan religious

Penjelasan diatas menunjukan adanya faktor ekonomi sebagai faktor yang mendasari terjadinya Doubel Burden yang dialami oleh perempuan penjual ikan di Desa Siddo Kecamatan Soppeng Riaja Kabupaten Barru. Sisi lain dapat dijelaskan tentang peningkatan ekonomi keluarga yang ditentukan oleh 
keterlibatan perempuan dalam ruang publik sebagai pekerja. Sukesi dalam Khairuddin (2002:35) Menjelaskan partisipasi perempuan yaitu menyangkut dua hal pertama, Peran tradisi atau domestik mencakup peran perempuan sebagai istri, ibu dan pengelola rumah tangga. Kedua, peran transisi meliputi pengertian perempuan sebagai tenaga kerja, anggota masyarakat dan manusia pembangunan. Pada peran transisi wanita sebagai tenaga kerja turut aktif dalam kegiatan ekonomis (mencari nafkah) di berbagai kegiatan sesuai dengan ketrampilan dan pendidikan yang dimiliki serta lapangan pekerjaan yang tersedia.

Menurut Ken Suratiyah (2003) bahwa keterlibatan perempuan dalam industri rumah tangga dipengaruhi oleh beberapa faktor, antara lain tekanan ekonomi, lingkungan keluarga yang sangat mendukung dalam bekerja, dan tidak ada peluang kerja lain yang sesuai dengan keterampilannya. Selain itu Ken Suratiyah juga mengungkapkan bahwa keterbatasan perempuan sebagai individu (human capital) dalam hal pendidikan, pengalaman, keterampilan kerja, dan kesempatan kerja, menyebabkan perempuan memasuki lapangan pekerjaan yang berstatus dan berupah rendah, sehingga kemungkinan besar perempuan mengalami eksploitasi (Irwan Abdullah, 2003:226).

Antara pendidikan dan ekonomi memiliki korelasi yang sangat penting dalam kehidupan sosial suatu masyarakat. Dimana pendidikan sangat menentukan akan ketrampilan yang dimiliki oleh setiap individu. Sebagai akibat dari minimnya pendidikan yang dimiliki, sebagian masyarakat yang ada di Desa Siddo Kecamatan Soppeng Riaja Kabupaten Baru memenuhi kebutuhan ekonomi keluarga dengan menjual ikan. Oleh sebab itu sangatlah nyata adanya bahwa pendidikan sesungguhnya memiliki peran yang sangat penting dalam kehidupan berbangsa dan bernegara, yakni upaya menciptakan sumber daya manusia yang berkualitas.

Pendidikan merupakan suatu faktor kebutuhan dasar untuk setiap manusia, karena melalui pendidikan upaya peningkatan kesejahteraan rakyat dapat diwujudkan. Pendidikan mempengaruhi secara penuh pertumbuhan ekonomi suatu negara. Hal ini bukan saja karena pendidikan akan berpengaruh terhadap produktivitas, tetapi juga akan berpengaruh pada kemampuan masyarakat. Pendidikan dapat menjadikan sumber daya manusia lebih cepat mengerti dan siap dalam menghadapi perubahan dan pembangunan suatu negara.

\section{Dampak Doubel Burden Perempuan Penjual Ikan di Awarannge Desa Siddo Kecamatan Soppeng Riaja Kabupaten Barru}

\section{a. Dampak positif terhadap keluarga}

Aktivitas pekerja perempuan dalam sektor publik memiliki tujuan yaitu untuk menambah pendapatan keluarga dalam rangka pemenuhan kebutuhan rumah tangga, sehingga meringankan beban suami. Dalam Irwan Abdullah (2003:226) Ken Suratiyah mengungkapkan bahwa keterlibatan perempuan dalam rahan publik umumnya dipengaruhi oleh beberapa faktor antara lain tekanan ekonomi, lingkungan keluarga yang sangat mendukung dalam bekerja, dan tidak ada peluang kerja lain yang sesuai dengan keterampilannya. Sejalan dengan pernyataan tersebut sebagian dari masyarakat Desa Siddo Kecamatan Soppeng Riaja Kabupaten Baru memenuhi segala kebutuhan ekonomi keluarga dengan menjual ikan. Penghasilan suami yang belum sepenuhnya dapat mencukupi kebutuhan rumah tangga membuat perempuan tidak bisa berdiam diri di rumah, mereka terdorong untuk mencari nafkah tambahan bagi keluarga. Sebab dalam kehidupan rumah tangga tugas mencari nafkah merupakan kewajiban dari seorang suami, akan tetapi tidak menutup kemungkinan bagi perempuan untuk bisa ikut berpartisipasi dalam membantu sang suami mencari nafkah diluar jika kondisi ekonomi keluarga masih serba kekukarang.

Hal ini telah dibuktikan oleh pekerja perempuan yang bekerja di menjual ikan di Desa Siddo Kecamatan Soppeng Riaja Kabupaten Baru. Hasil jualan ikan yang diperoleh dapat menambah pendapatan dan dimanfaatkan untuk memenuhi kebutuhan dalam rumah tangganya. Seperti yang diutarakan oleh beberapa informan diatas. Penghasilan yang diperolehnya dapat dipergunakan untuk berbagai macam kebutuhan rumah tangga, bahkan bisa membiaya pendidikan anak pada tingkat perguruan tinggi. Sebab disadari atau tidak kebutuhan rumah tangga tidak mungkin hanya mengandalkan nafkah dari suami saja. Hal ini lah yang mendorong perempuan untuk berperan juga dalam bekerja mencari nafkah.

Disisi lain Bekerjanya perempuan sebagai penjual ikan di Desa Siddo Kecamatan 
Soppeng Riaja Kabupaten Baru sangat menyita waktu mereka dalam seharinya. Perempuan yang bekerja lebih banyak menghabiskan waktunya di tempat jualan sehingga waktu untuk bertemu dengan anggota keluarga terbatas, namun hal ini tidak membuat hubungan mereka menjadi tidak harmonis, tetapi malah memunculkan rasa saling pengertian antar anggota keluarga, terutama dengan antara suami dan istri. Keduanya saling menyadari peran masing-masing. Seorang lakilaki sebagai suami tetap menyadari perannya sebagai kepala rumah tangga yang harus memberikan nafkah untuk keluarganya. Seorang perempuan yang berperan sebagai seorang istri dan juga ibu tetap menjalankan perannya dengan baik yaitu mengurus rumah tangga, suami, dan anak-anaknya walaupun mereka harus bekerja.

\section{b. Dampak negatif terhadap keluarga}

Keterlibatan perempuan dalam dunia kerja tidak akan pernah bisa merubah peranan perempuan dalam rumah tangga. Banyaknya tanggung jawab yang harus dijalankan oleh pekerja perempuan membuat mereka memiliki beban kerja ganda. Hal ini yang dirasakan oleh perempuan yang bekerja sebagai penjual ikan di Desa Siddo Kecamatan Soppeng Riaja Kabupaten Barru. Adanya anggapan bahwa kaum perempuan tidak pantas untuk menjadi kepala rumah tangga, berakibat bahwa semua pekerjaan domestik menjadi tanggung jawab perempuan. Beban ini akan terasa sangat berat dirasakan bagi perempuan yang juga bekerja di sektor publik untuk mencari nafkah tambahan.

Beban kerja ganda yang ditanggung oleh seorang pekerja perempuan dapat menghabiskan banyak waktu, tenaga dan pikiran. Waktu yang dimiliki pekerja perempuan lebih banyak digunakan untuk kegiatan yang berkaitan dengan pekerjaan (sektor publik) dan kegiatan dalam rumah tangganya (sektor domestik Apalagi kalau jualannya banyak yang belum laku, mereka masih harus menjual sampai malam hari. sehingga waktu istirahat dan waktu untuk berkumpul dengan keluarganya mereka menjadi terbatas.

Curahan waktu yang dimiliki oleh pekerja perempuan yang banyak dihabiskan untuk bekerja juga berdampak pada keluarga yaitu waktu pekerja perempuan untuk berkumpul dengan anggota keluarganya, terutama dengan suami dan anaknya menjadi terbatas. Apalagi bagi mereka yang sama-sama sibuk bekerja. Mereka hanya dapat bertemu di waktu pagi hari sebelum berangkat kerja dan malam hari menjelang tidur malam. Kurangnya waktu ini akan memiliki dampak yang cukup besar bagi keharmonisan rumah tangga. Disamping komunikasi dan sosialisasi dalam keluarga menjadi sangat jarang terjadi. Dikutip dalam Bagon dan Dwi (2007:58) Friedman menjelaskan bahwa fungsi keluarga meliputi:

a) Fungsi afektif, adalah fungsi keluarga yang utama untuk mengajarkan segala sesuatu untuk mempersiapkan anggota keluarga berhubungan dengan orang lain.

b) Fungsi sosialisasi, adalah fungsi mengembangkan dan tempat melatih anak untuk kehidupan sosial sebelum meninggalkan rumah untuk berhubungan dengan orang lain diluar rumah.

c) Fungsi reproduksi, adalah fungsi untuk mempertahankan generasi dan menjaga kelangsungan keluarga.

d) Fungsi ekonomi, adalah keluarga berfungsi untuk memenuhi kebutuhan keluarga secara ekonomi dan tempat untuk mengembangkan kemampuan individu dalam meningkatkan penghasilan untuk memenuhi kebutuhan keluarga.

e) Fungsi perawatan atau pemeliharaan kesehatan, yaitu fungsi untuk mempertahankan keadaan kesehatan anggota keluarga agar tetap memiliki produktivitas tinggi.

Berdasarkan pendapat diatas bahwa keluarga memiliki peran yang cukup penting di dalam keluarga terjadi proses sosialiasi dan komunikasi antara anggota keluarga. Dimana orang tua menjadi guru pertama bagi seorang anak untuk menanamkan nilai-nilai sosial yang dibutuhkan anak dalam kehidupannya. Tetapi kenyataan ini sangat jarang terjadi pada keluarga ibu-ibu penjual ikan di desa Siddo Kecamatan Soppeng Riaja Kabupaten Barru.

\section{SIMPULAN DAN SARAN}

Dari sejumlah uraian yang diatas, dapat di tarik beberapa kesimpulan, antara lain sebagai berikut:

1. Motivasi bagi ibu-ibu menjual ikan yang ada di desa Siddo kecamatan soppeng kabupaten barru yaitu Faktor Ekonomi (Kebutuhan Finansial) dan Faktor Pendidikan. Faktor ekonomi menyangkut keterbatasan ekonomi keluarga pada keluarga penjual ikan Desa Siddo Kecamatan Soppeng Riaja Kabupaten Barru untuk mencari nafkah tambahan di luar rumah, disamping ketidak mampuan 
sang suami memenuhi kebutuhan rumah tangga secara maksimal. Sedangkan faktor pendidikan menyangkut kurangnya ketrampilan yang dmiliki oleh para ibu-ibu untuk mendaptkan pekerjaan yang layak yang dapat memberikan keutungan yang lebih besar dibandingkan keutungan jualan ikan yang masih sangat sedikit yaitu hanya antara Rp. 20.000- 100.000 per hari.

2. Dampak yang dialami oleh perempuan penjual ikan pada Desa Siddo Kecamatan Soppeng Riaja Kabupaten Barru yaitu dampak negatif dan postif. Dampak positif antara lain menambah penghasilan keluarga dan meningkatkan rasa kerja sama antara anggota keluarga. Sedangkan dampak negatif yaitu sosialisasi dan komunikasi dalam anggota keluarga menjadi sangat terbatas, karena waktunya yang dimiliki oleh sang ibu/istri lebih banyak dihabiskan untuk berjualan.

Berdasarkan hasil penelitian maka dapat diberikan beberapa saran-saran sebagai berikut:

1. Diharapkan kepada para perempuan penjual ikan agar dapat tetap mempetrhatikan kehidupan rumah tangga terutama anak-anak dan pendidikannya. Sebisa mungkin agar pendidikan anak-anaknya diperhatikansuatu saat nanti mereka dapat merubah nasib dirinya dan keluarganya dan mengangkat derajat ekonomi keluarganya dengan tidak menjadi penjual ikan seperti yang selama ini mereka lakoni.

2. Kepada anak-anak informan, diharapkan agar tetap bersekolah seperti harapan orang tuanya agar dapat meraih pekerjaan yang lebih baik dikemudian hari setelah dewasa dan tidak menurunkan pekerjaan ini pada diri mereka.

3. Kepada pemerintah setempat agar dapat lebih memperhatikan masyarakatnya terutama kaum perempuan dengan memberikan pelatihan keterampilan yang bukan untuk menggantikan profesi yang dilakoni mereka saat ini tetapi keterampilan tambahan yang bisa mereka lakoni disaat mereka hanya menjual paroh waktu, yaitu saat mereka tidak menjual dipasar karena tidak sedang berlangsung hari pasar, sehingga dapat menambah penghasilan tanpa harus meninggalkan rumah mereka.

\section{DAFTAR PUSTAKA}

Abdullah, I. (Ed). 2007. Sangkan Peran Gender. Pustaka Pelajar dan Pusat Penelitian Kependudukan. Yogyakarta

Ahmadi, Abu. 2002. Psikologi Sosial. Jakarta. Rineka Cipta.

Bainar, 2008. Wacana Perempuan dalam Keindonesiaan dan Kemodernan. Pustaka Cidesindo. Jakarta

Faqih, Masyur. 2006. Analisis Gender dan Transformasi Sosial. Pustaka Pelajar. Yogyakarta

Ihromi 2006. Pokok-Pokok Antropologi Budaya (Edisi Terbaru). Yayasan Obor Indonesia. Jakarta

Ihromi. 2009. Para Ibu yang Berperan Tunggal dan Berperan Ganda. Lembaga Penerbit Fakultas Ekonomi. Jakarta

Jojogyo, Pubjiwati. 2005. Sosiologi Pembangunan. IKIP. Jakarta

Keppi, Sukesi. 2015. Gender Dan Kemiskinan Di Indonesia. Lembaga Penerbitan \& Percetakan Universitas Brawijaya. Malang

Khairuddin. 2002. Sosiologi Kelurga. Yogyakarta : Liberty.

Mayling OG, dkk. 2006. Perempuan Indonesia Dulu dan Kini, (Edisi Revisi). Gramedia Pustaka Utama. Jakarta

Ritzer, George. 2012. Teori Sosiologi, Dari Sosiologi Klasik Sampai Perkembangan Terakhir Postmodern. Edisi 8. Pustaka Pelajar. Yogyakarta.

Saptari, Ratna dan Brigitte Holzer. 2007. Perempuan Kerja dan Perubahan sosial. PT.Anem Kosong Anem. Jakarta

Soetrisno, Loekman. 2007. Kemiskinan, Perempuan, dan Pemberdayaan. Penerbit Kanisius. Yogyakarta

Sugiyono. 2012. Metode Penelitian Kuantitatif Dan Kualitatif. Bandung: PT Alfabeta.

Kusumawati, Yunita. 2012. Peran Ganda Perempuan Pemetik Teh. Jurnal Komunikasi. Univ.Negeri Semarang. Jawa Tengah

Salaa, Jeiske. 2015. Peran Ganda Ibu Rumah Tangga Dalam Meningkatkan Ekonomi Keluarga di Desa Tarohan Kecamatan Beo Kabupaten Kepulauan Talaud. Jurnal Holistik. Sulawesi Utama 
Suryadi, Denrich. 2004. Gambaran Konflik Emosional Dalam Menentukan Prioritas Peran Ganda”. Jurnal Ilmiah Psikologi. Yogyakarta

Https://Www.Academia.Edu//Peran_Publik_Vs _Peran_Domestik_Perempuan_Daripersp ektif_Feminisme_Analisis_Pada_Tayanga n_Tupperware_She_Can (Dikutip pada Tanggal 21 September 2017)

Https://www.academia.edu//Problem_Definisi_ Gender_Kajian_atas_Konsep_Nature_dan _Nurture (Dikutip pada Tanggal 21 September 2017) 